\title{
PENGEMBANGAN INSTRUMEN PENGUKUR TINGKAT KEPUASAN SISWA TERHADAP KUALITAS PELAYANAN PENDIDIKAN DI SEKOLAH
}

\section{Tata Suharta}

SMA Negeri I Sobang

Kabupaten Lebak, Jawa Barat

\begin{abstract}
The purpose of this study is to develop an instrument measuring the level of students satisfaction of educational services quality in the high school. Students satisfaction is the level of a student's felt state resulting from comparing a product's perceived performance or outcome in relations to the student's expectation. Level of the student satisfaction with five dimensions consists of tangible, reliability, responsiveness, assurance, and emphaty. The research sample taken using simple random sampling technique. Development of items based on expert judgement with Likert's scales. Based on the items which have been selected through the study and validation of expert panelists with interrater reliability coefficient values produced 38 selected items. This instrument has been tested to 200 students of secondary school in Kabupaten Tangerang. Instruments in the research is made in two coulomns respons, consists of performance and expectation. Empirically test through the first and second trials testing through confirmatory factor analysis (CFA) with Maximum Likelihood method (ML) values obtained factor loading above 0,5. From a reliability coefficient calculation shows that the value of multidimensional reliability coefficients more than 0.9 and average variance extracted (AVE) values more than 0.5 in the first and second trials, which means that the level of validity and reliability of the instrument measuring the level students satisfaction of service quality in high school classified as very high. It can be concluded that the level of students satisfaction measuring instrument has good construct validity and reliability.
\end{abstract}

\section{Keywords}

construct validity, construct reliability, instrument development, students satisfaction, educational service quality

\section{ABSTRAK}

Tujuan dari penelitian ini adalah untuk mengembangkan instrumen pengukur tingkat kepuasan siswa terhadap kualitas pelayanan pendidikan di Sekolah Menengah Atas. Kepuasan siswa adalah tingkat perasaan siswa setelah membandingkan kinerja atau hasil yang dirasakan dibandingkan dengan harapan siswa. Tingkat kepuasan siswa terdiri dari lima dimensi, yakni: tangible, reliability, responsiveness, assurance, dan emphaty. Sampel penelitian ini diambil dengan menggunakan metode sampling acak sederhana. Pengembangan pernyataan-pernyataan instrumen didasarkan pada penilaian pakar menggunakan skala Likert. Melalui telaah pakar dan validasi panelis berdasarkan nilai koefisien reliabilitas interrater terpilih 38 butir. Instrumen diujicobakan pada 200 siswa SMA di Kabupaten Tangerang. Satu perangkat instrumen ini dikembangkan dengan dua kelompok alternatif jawaban, yakni: kinerja dan harapan siswa. Secara empiris melalui ujicoba pertama dan ujicoba kedua melalui pengujian analisis faktor konfirmatori dengan metode Maximum Likelihood (ML) didapatkan nilai loading factor di atas 0,5. Dari perhitungan nilai koefisien reliabilitas multidimensi menunjukkan bahwa nilai koefisien reliabilitas konstruk lebih besar dari 0,9 dan nilai Average Variance Extracted (AVE) lebih besar dari 0,5 pada ujicoba pertama dan kedua, yang berarti tingkat validitas dan reliabilitas instrumen pengukur tingkat kepuasan siswa terhadap kualitas pelayanan pendidikan tergolong sangat tinggi. Jadi dapat disimpulkan bahwa instrumen pengukur tingkat kepuasan siswa terhadap kualitas pelayanan pendidikan di sekolah ini telah memiliki validitas dan reliabilitas konstruk yang baik.

\section{Kata kunci}

validitas konstruk, reliabilitas konstruk, pengembangan instrumen, kepuasan siswa, kualitas pelayanan pendidikan 


\section{Pendahuluan}

Pengukuran kualitas pelayanan pendidikan merupakan elemen penting dalam menyediakan pelayanan pendidikan yang lebih efisien dan efektif. Kualitas suatu sekolah tidak dapat diukur hanya dari bangunan sekolah yang bagus atau sarana prasarana yang lengkap. Kualitas sekolah lebih ditentukan oleh kualitas layanan yang diberikan sekolah melalui pengukuran kepuasan pelanggannya terhadap layanan pendidikan yang diberikan, dalam hal ini para peserta didik (siswa) sebagai pelanggan primer.

Dalam memberikan pelayanan pendidikan, sekolah harus mengacu pada standar nasional pendidikan sebagai tolok ukur pelaksanaan pelayanan/jasa pendidikan di lingkungan suatu sekolah. Adapun ruang lingkup standar nasional pendidikan tertuang dalam Peraturan Pemerintah Republik Indonesia Nomor 19 Tahun 2005 tentang Standar Nasional Pendidikan. Kepuasan siswa terhadap layanan pendidikan ini harus mempunyai tolok ukur kualitas pelayanan berdasarkan standar tersebut sehingga dapat diukur sejauh mana kualitas pelayanan tersebut.

Kepuasan pelanggan merupakan perbedaan antara harapan dan kinerja yang dirasakan (Supranto, 20I I: 224). Jadi, pengertian kepuasan pelanggan berarti bahwa kinerja suatu barang atau jasa sekurang-kurangnya sama dengan apa yang diharapkan. Kepuasan adalah tingkat perasaan seseorang setelah membandingkan kinerja atau hasil yang dirasakan dengan harapannya (Kottler dan Keller, 2012: 128). Jadi kepuasan adalah kesimpulan dari interaksi antara harapan dan pengalaman sesudah memakai jasa atau pelayanan yang diberikan. Oleh karena itu, kepuasan pelanggan sangat ditentukan oleh kualitas dari suatu barang/jasa yang diharapkan oleh pelanggan. Pelanggan akan merasa puas jika kualitas dari suatu barang/jasa sesuai dengan apa yang diharapkannya.

Ada dua faktor utama yang mempengaruhi kualitas dari layanan, yaitu: persepsi pelanggan atas pelayanan (perceived service) dan harapan pelanggan atas pelayanan (expected service). Kualitas pelayanan yang baik harus berorientasi pada persepsi pelanggan dan bukanlah berdasarkan sudut pandang atau persepsi pihak penyedia jasa. Kepuasan pelanggan atas pelayanan jasa dapat diukur dari kesenjangan antara pelayanan yang diharapkan (expected service) dan persepsi pelanggan (perceived service) tentang pelayanan yang diterima (Parasuraman, Zeithaml, dan Berry, 1993: II-12). Dalam kaitannya dengan definisi kepuasan secara eksplisit ada tiga rumusan hal penting, yaitu: (a) ringkasan reaksi afektif dari berbagai intensitas rangsangan, (b) dibatasi dalam rentang waktu yang terbatas, dan (c) terarah kepada aspek fokal dari produk yang dikonsumsi (Giese dan Cote, 2002: 14-I5).

Kepuasan ditentukan oleh dua variabel kognitif, yaitu: variabel harapan (expectation), yaitu: keyakinan akan kinerja sebelum membeli barang/jasa dan variabel diskonfirmasi (disconfirmation), yaitu: perbedaan persepsi sebelum membeli barang/jasa dan setelah membeli barang/jasa tersebut (Oliver, 1980: 462). Jadi, kepuasan atau ketidakpuasan konsumen merupakan dampak dari perbandingan antara harapan pelanggan sebelum pembelian dengan sesungguhnya yang diperoleh pelanggan dari produk atau jasa tersebut. Apabila kinerja produk atau jasa masih di bawah harapan, maka pelanggan akan kecewa/tidak puas (diskonfirmasi negatif), dan apabila kinerja sudah sesuai dengan harapan, maka pelanggan akan puas (diskonfirmasi positif).

Kualitas pelayanan terdiri dari lima dimensi, yaitu: bukti fisik (tangible), keandalan (reliability), daya tanggap (responsiveness), jaminan (assurance), dan empati (emphaty) (Parasuraman, Zeithaml, dan Berry, 1988: 23). Sedangkan Sureshchandar, et al. mengidentifikasi lima faktor/dimensi kualitas pelayanan yang sangat kritis dari sudut pandang pelanggan: (I) inti dari layanan atau konten produk layanan dari jasa, (2) unsur manusia dari aspek layanan seperti reliability, assurance, tangible, empathy, dan responsiveness, (3) sistemasi pelayanan, proses, prosedur yang berlaku, dan teknologi yang mendukung pelayanan, (4) unsur yang terlihat (tangible) seperti peralatan pelayanan, penampilan karyawan, dan lingkungan yang mendukung pelayanan atau umumnya dikenal sebagai "servicescape", dan (5) tanggung jawab 
sosial berupa perilaku etis dari penyedia layanan (Sureshchandar, Rajendran, dan Anantharaman, 2002: 364).

Dimensi pertama dari kualitas pelayanan adalah tangible (bukti langsung), merupakan kemampuan untuk memberikan fasilitas fisik sekolah serta perlengkapan pembelajaran yang memadai menyangkut penampilan staff dan karyawan serta sarana umum yang terlihat langsung. Adapun indikatornya meliputi fasilitas fisik, perlengkapan sarana prasarana, dan kondisi lingkungan serta penampilan karyawan.

Kedua dimensi reliability (keandalan), berkaitan dengan kemampuan suatu perusahaan jasa untuk memberikan layanan yang akurat sejak pertama kali tanpa membuat kesalahan apapun dan menyampaikan jasanya sesuai dengan waktu yang telah disepakati. Adapun indikator dari reliability meliputi waktu pelayanan yang cepat, relevan dan akurat, pelayanan menjanjikan yang dapat dipercaya, serta memberikan akurasi pelayanan pada semua pelanggan.

Ketiga dimensi responsiveness (daya tanggap), berkenaan dengan kesediaan dan kemampuan para staff dan karyawan untuk membantu para pelanggan dan merespon permintaan pelanggan, serta menginformasikan kapan jasa akan diberikan dan kemudian memberikan jasa secara tepat. Indikatornya berkaitan dengan proses pemberian jasa yang interaktif dan variatif, kepedulian terhadap pelanggannya, penanganan permasalahan atau kebutuhan pelanggan secara tepat sehingga memungkinkan untuk mengembangkan kreativitas dan kapasitasnya.

Keempat dimensi assurance (jaminan), yakni: perilaku para karyawan mampu menumbuhkan kepercayaan pelanggan terhadap perusahaan dan perusahaan dapat menciptakan rasa aman bagi pelanggannya. Jaminan juga berarti bahwa para karyawan selalu berperilaku baik serta menguasai pengetahuan dan keterampilan yang dibutuhkan untuk menangani setiap pertanyaan atau masalah pelanggan. Indikatornya meliputi kompetensi atau pengetahuan yang dimiliki staff atau karyawan memadai, perilaku yang ditunjukkan staff atau karyawan, serta yang menyangkut masalah keamanan di lingkungan sehingga pelanggan merasa aman dan nyaman ketika berada di lingkungan perusahaan.

Kelima dimensi emphaty (empati), berarti perusahaan memahami masalah para pelanggannya dan bertindak demi kepentingan pelanggan sehingga pelayanan yang diberikan sekolah sepenuh hati. Indikator dari empati meliputi perhatian semua staff kepada pelanggannya, terjalin komunikasi yang baik antara pelanggan dan penyedia jasa, serta kemudahan untuk berkomunikasi atau dihubungi.

Instrumen atau alat ukur kepuasan ini harus benar-benar dapat mengukur dengan tepat persepsi atau sikap pelanggan tersebut melalui dimensi-dimensi kualitas pelayanan. Alat pengukur yang dapat digunakan untuk mengukur kepuasan siswa adalah non tes yang berupa instrumen. Hasil dari instrumen pengukur kepuasan siswa terhadap layanan ini dapat digunakan di sekolah atau lembaga pendidikan untuk mengetahui tingkat kepuasan siswa terhadap pelayanan yang diberikan. Data yang diperoleh dari hasil angket/kuesioner kinerja pelayanan yang diberikan sekolah dibandingkan dengan harapan atau persepsi siswa terhadap kualitas yang diharapkan. jika kinerja pelayanan sekolah lebih besar dari harapan maka siswa akan sangat puas, jika kinerja pelayanan yang diberikan sama dengan harapan siswa maka siswa akan merasa puas, dan jika pelayanan yang diberikan di bawah harapan siswa maka siswa akan merasa tidak puas.

Untuk itu penelitian ini difokuskan pada penyusunan dan pengembangan instrumen pengukur tingkat kepuasan siswa terhadap kualitas pelayanan pendidikan di sekolah terutama validasi konstruk dengan menggunakan analisis faktor konfirmatori dengan indikator-indikator dari dimensi-dimensi yang membangun konstruk kepuasan siswa terhadap kualitas pelayanan pendidikan di sekolah, yaitu: (I) tangible, (2) responsiveness, (3) reliability, (4) assurance, dan (5) emphaty. Penelitian ini juga berfokus pada estimasi reliabilitas konsistensi internal dengan menggunakan koefisien alpha berstrata dan reliabilitas konstruk dari kepuasan siswa serta menguji ketepatan model teoretis yang dibuat peneliti dengan menggunakan hasil analisis faktor konfirmatori. 


\section{Metode Penelitian}

Pada penelitian ini digunakan metode survei dengan memberikan angket/kuesioner kepada responden. Survei digunakan dalam pengumpulan data yang bertujuan untuk mengungkap fakta berdasarkan gejala yang ada pada responden. Metode yang berorientasi pada stimulus atau respon dari para responden yang digunakan untuk menentukan letak kontinum, kemudian angka yang dihasilkan dijadikan skor bagi butir yang disetujui. Penelitian ini menggunakan metode sampling acak sederhana.

Kepuasan siswa adalah nilai yang diperoleh dari suatu perbandingan kinerja yang dirasakan (perceived service) dengan harapan siswa (expected service) yang diukur melalui lima dimensi kualitas layanan, yakni: (I) sesuatu yang terwujud (tangible) sebanyak 13 butir, (2) kehandalan (reliability) sebanyak 8 butir, (3) daya tanggap (responsiveness) sebanyak 6 butir, (4) jaminan (assurance) sebanyak 6 butir, dan (5) empati (emphaty) sebanyak 5 butir. Jadi instrumen sebanyak 38 butir. Data skor yang diperoleh dari hasil ujicoba dianalisis untuk melihat validasi konstruk serta koefisien reliabilitasnya dengan menggunakan analisis faktor konfirmatori dengan menggunakan metode ML (Maximum Likelihood). Dimensi dan indikator dari konstruk kepuasan siswa dapat dilihat pada Tabel I.

Definisi operasional kepuasan siswa sebagai pelanggan internal adalah nilai yang diperoleh dari sesuatu perbandingan kinerja yang dirasakan dengan harapan siswa yang diukur melalui lima dimensi kualitas layanan. Tiga puluh delapan butir pernyataan tersebut diperoleh dari 40 butir pernyataan awal setelah ditelaah oleh 5 orang pakar dan diujicobakan pada 20 orang panelis.

Tabel I. Dimensi dan Indikator Instrumen Kepuasan Siswa

\begin{tabular}{lll}
\hline No & Dimensi & Indikator \\
\hline I & Tangible & $\begin{array}{l}\text { Kondisi penampilan prasa } \\
\text { rana sekolah, perlengkap } \\
\text { an sarana pembelajaran, } \\
\end{array}$ \\
& & $\begin{array}{l}\text { dan fasilitas fisik sekolah } \\
\text { Pelayanan yang dapat di } \\
\text { percaya, dan akurasi pela } \\
\text { yanan berusaha mengam } \\
\text { bil tindakan logis }\end{array}$
\end{tabular}

\begin{tabular}{|c|c|c|}
\hline 3 & Responsiveness & $\begin{array}{l}\text { Kemudahan pelayanan, } \\
\text { dan respon terhadap } \\
\text { siswa }\end{array}$ \\
\hline 4 & Assurance & $\begin{array}{l}\text { Kompetensi dan } \\
\text { keamanan }\end{array}$ \\
\hline & Emphaty & $\begin{array}{l}\text { Perhatian kepada siswa, } \\
\text { dan kemudahan } \\
\text { komunikasi }\end{array}$ \\
\hline
\end{tabular}

Definisi operasional kepuasan siswa sebagai pelanggan internal adalah nilai yang diperoleh dari suatu perbandingan kinerja yang dirasakan dengan harapan siswa yang diukur melalui lima dimensi kualitas layanan. Tiga puluh delapan butir pernyataan tersebut diperoleh dari 40 butir pernyataan awal setelah ditelaah oleh 5 orang pakar dan diujicobakan pada 20 orang panelis.

Setiap butir dalam pernyataan merupakan suatu keadaan atau perasaan responden yang berkaitan dengan kepuasan siswa terhadap layanan pendidikan. Butir-butir pernyataan tersebut disertai dengan skala Likert dengan lima pilihan, yaitu: Sangat Penting (SP), Penting (P), Biasa-biasa saja (Bs), Tidak Penting (TP), dan Sangat Tidak Penting (STP) untuk mengukur harapan atau persepsi siswa terhadap kualitas pelayanan dan Sangat Puas (SPs), Puas (Ps), Raguragu (R), Tidak Puas (TPs), dan Sangat Tidak Puas (STPs) untuk mengukur kinerja sekolah.

\section{Hasil Penelitian dan Pembahasan}

Berdasarkan telaah dari para pakar, diperoleh penilaian yang relatif sama mengenai konstruk dari kepuasan siswa. Secara umum indikator yang disusun dinilai sudah mewakili dimensi dari konstruk kepuasan siswa. Indikatorindikator yang disusun merupakan representasi dari penjabaran dimensi dari konstruk yang telah didefinisikan. Dengan kata lain konstruksi butir sudah sesuai dengan indikatornya.

Para pakar memberi beberapa masukan terhadap butir-butir pernyataan yang disusun berdasarkan indikatornya. Ada butir pernyataan yang dapat membingungkan responden dan saling tumpang tindih (overlap), misalnya butir tersebut masuk dalam dimensi responsiveness (daya tanggap), tapi mengindikasikan masuk ke dimensi tangible (bukti fisik). Butir tersebut diperbaiki karena membingungkan dan dapat bermakna 
ambigu. Butir pernyataan ini juga saling tumpang tindih (overlap), yakni: masuk dimensi tangible (bukti fisik). Menurut pakar, ada butir yang tidak sesuai dengan indikatornya, misalnya pada indikator keamanan ternyata butirnya tidak merepresentasikan indikatornya, seharusnya indikator keamanan itu berkaitan dengan hal-hal yang bersifat ancaman terhadap keselamatan siswa atau barang yang dimilikinya serta kepastian hukum atau peraturan. Butir yang tidak merepresentasikan indikatornya tersebut dibuang dan diganti dengan butir pernyataan baru yang lebih representatif sesuai dengan saran pakar.

Pakar juga menilai beberapa butir pernyataan yang tidak mengukur konsep dimensi atau indikatornya. Butir tersebut tidak dapat digunakan untuk mengukur konsep karena bukan suatu ukuran yang menjadi bahan penilaian untuk mengukur indikator. Contoh butir yang tidak dapat mengukur konsep ada dua butir, butir tersebut dibuang karena memang tidak mengukur indikatornya. Bahasa yang digunakan dalam penyusunan perangkat non tes dinilai para pakar cukup komunikatif. Namun demikian, terdapat beberapa kalimat disarankan untuk diperbaiki karena sulit dipahami, membingungkan, dan dimungkinkan terjadinya salah interpretasi. Pakar juga menyarankan untuk setiap butir hanya menanyakan satu pernyataan atau hanya memuat satu pemikiran (one thought), hal ini biasanya terdapat pada butir yang mengandung kata "dan", "atau".

Apabila suatu butir menanyakan lebih dari satu pertanyaan, responden mungkin bingung kalau dia akan menjawab bagian yang satu secara positif sedangkan bagian yang lainnya secara negatif. Jawaban yang positif untuk tipe butir ini akan menunjukkan bahwa responden setuju bagian tersebut, sebaliknya jawaban yang negatif dapat diartikan bahwa responden tidak setuju dengan salah satu bagian atau tidak setuju keduanya. Pakar menyarankan butir yang diinterpretasikan lebih dari satu cara tersebut dipecah menjadi dua butir pernyataan baru atau menghapus salah satu kata.

Dari pemaparan berdasarkan validitas konstruk dan keterbacaan butir pernyataan, penggunaan tata bahasa, dan penulisannya, maka sesuai masukan para pakar ada 2 butir yang dianulir dan tidak dimasukkan dalam analisis karena tidak dapat mengukur konsep kepuasan. Oleh karena itu terdapat 38 butir yang memenuhi syarat pada tes performansi pengukuran kepuasan siswa yang akan digunakan untuk keperluan analisis uji validitas dan reliabilitas.

Hasil perbaikan dan penyempurnaan pada perangkat non tes kemudian diperiksa kembali oleh 20 panelis dalam pengujian secara rasional, untuk menentukan tingkat kecocokan butir pernyataan dan reliabilitas antar raternya. Dari uji kecocokan butir pernyataan dengan menggunakan Content Validity Ratio (CVR) dari Lawshe yang dilakukan oleh 20 panelis (rater) terlihat bahwa semua butir pernyataan pada masing-masing dimensi sudah cocok dan sesuai dengan konstruksi dimensinya. Hal ini terlihat dari nilai CVR hitung yang semuanya melebihi dari nilai kritis CVR tabel pada taraf signifikansi 5\% dan jumlah rater 20 , yaitu: 0,42 . Sehingga semua butir dapat dikatakan layak dan cocok digunakan untuk mengukur konstruk kepuasan siswa. Perhitungan reliabilitas konstruk penilaian dari panelis terhadap instrumen kepuasan siswa menggunakan rumus Hoyt dan hasil perhitungan reliabilitas interrater para panelis diperoleh koefisien reliabilitas untuk masing-masing dimensi yang bernilai lebih besar dari 0,7 . Nilai ini tergolong cukup tinggi, sehingga instrumen kepuasan siswa ini dinyatakan reliabel.

Tabel 2. Koefisien Reliabilitas Hoyt Instrumen Kepuasan Siswa

\begin{tabular}{lll}
\hline No & Dimensi & $\begin{array}{l}\text { Koefisien } \\
\text { Reliabilitas }\end{array}$ \\
\hline I. & Tangible & 0,75 \\
2. & Reliability & 0,73 \\
3. & Responsiveness & 0,72 \\
4. & Assurance & 0,71 \\
5. & Emphaty & 0,72 \\
\hline
\end{tabular}

Dari hasil perhitungan ujicoba pengujian validitas instrumen kinerja bahwa 38 butir valid. Sedangkan uji reliabilitas dengan menggunakan formula koefisien reliabilitas Alpha Cronbach pada masing-masing dimensi didapatkan nilai koefisien reliabilitas untuk masing-masing dimensi 
mempunyai nilai Alpha Cronbach yang bernilai lebih besar dari 0,7. Berdasarkan kriteria yang dikemukakan oleh Naga (2012: 24I), dapat dikatakan bahwa alat ukur yang digunakan dalam penelitian ini mempunyai reliabilitas yang dapat diterima dan baik. Nilai koefisien reliabilitas tersebut dikatakan tinggi, sehingga instrumen kepuasan siswa ini digunakan sebagai alat ukur yang mempunyai konsistensi internal yang baik.

Pengujian model pengukuran secara keseluruhan (overall) dengan menggunakan analisis faktor konfirmatori bertujuan untuk menguji model yang terbentuk berdasarkan butir yang membangun dimensi, dan dimensi-dimensi pembentuk konstruk kepuasan siswa. Uji ini dilakukan untuk mengevaluasi derajat kecocokan/ goodness of fit (GOF) antara data dengan model. Uji kecocokan untuk keseluruhan model (overall model) melibatkan model struktural dan model pengukuran secara terintegrasi yang dibagi menjadi tiga kelompok pengujian, yaitu: ukuran kecocokan absolut (absolute fit measures), ukuran kecocokan model inkremental (incremental fit measures), dan ukuran kecocokan parsimoni (parsimonious fit measures) (Latan, 20I3: 49). Sebagian besar ukuran GOF menunjukkan kecocokan yang baik sehingga dapat disimpulkan bahwa kecocokan keseluruhan model adalah baik (model fit).

Validitas konvergen dapat dilihat nilai loading factor tiap-tiap item dari masing-masing dimensi dan nilai average variance extracted (AVE) dengan kriteria, yaitu: nilai loading factor lebih dari 0,5 (Hair, 2010: 709) dan nilai average variance extracted (AVE) masing-masing konstruk minimal 0,50 dapat diterima (Fornell dan Larcker, 198I: 46). Selanjutnya untuk mengevaluasi model pengukuran secara keseluruhan dengan menghitung nilai reliabilitas konstruk $(C R)$ untuk tiap konstruk atau dimensi. Rule of thumb dari koefisien reliabilitas konstruk adalah 0,7 (Hair, 20 10: 7I0). Nilai average variance extracted (AVE) dan reliabilitas konstruk (construct reliability) tidak dikeluarkan dalam output Lisrel, sehingga harus dihitung secara manual. Untuk menghitung AVE dan CR dilakukan secara bertahap, pertama untuk first order konstruk dan kedua untuk second order konstruk.
Berikut rumus untuk menghitung average variance extracted (AVE) dan reliabilitas konstruk.

$$
\begin{gathered}
A V E=\frac{\left(\text { l) } \sum_{i=1}^{k} \lambda_{i}^{2}\right.}{\sum_{i=1}^{k} \lambda_{i}^{2}+\sum_{i=1}^{k}\left(1-\lambda_{i}^{2}\right)} \\
C R=\frac{\left(\sum_{i=1}^{k} \lambda_{i}\right)^{2}}{\left(\sum_{i=1}^{k} \lambda_{i}\right)^{2}+\sum_{i=1}^{k}\left(1-\lambda_{i}^{2}\right)}
\end{gathered}
$$

Di mana $\lambda_{i}=$ nilai loading factor terstandarisasi masing-masing indikator/item.

Untuk menghitung AVE dan $C R$ dilakukan secara bertahap, pertama untuk first order konstruk dan kedua untuk second order konstruk. Berikut hasil perhitungan nilai AVE dan $C R$ untuk setiap konstruk ditunjukkan oleh Tabel 3. Nilai koefisien reliabilitas konstruk ini dikategorikan tinggi, sehingga dapat dikatakan bahwa model yang didapatkan ini reliabel.

Tabel 3. Nilai AVE dan Reliabilitas Konstruk pada Model Ujicoba I (Kinerja)

\begin{tabular}{ccc}
\hline Konstruk & AVE & $C R$ \\
\hline Kepuasan Siswa & 0,622 & 0,984 \\
\hline
\end{tabular}

Nilai loading factor masing-masing item pada tiap-tiap dimensi pada instrumen kinerja dapat dilihat pada Gambar I.

Dari Gambar I dapat diketahui bahwa seluruh indikator signifikan karena memiliki nilai loading factor $>0,5$. Hal ini dapat dikatakan bahwa item/indikator penyusun masing-masing dimensinya dapat menjelaskan konstruk latennya dengan baik. Hal ini memberikan makna bahwa seluruh indikator memberikan informasi yang signifikan terhadap variabel latennya. 


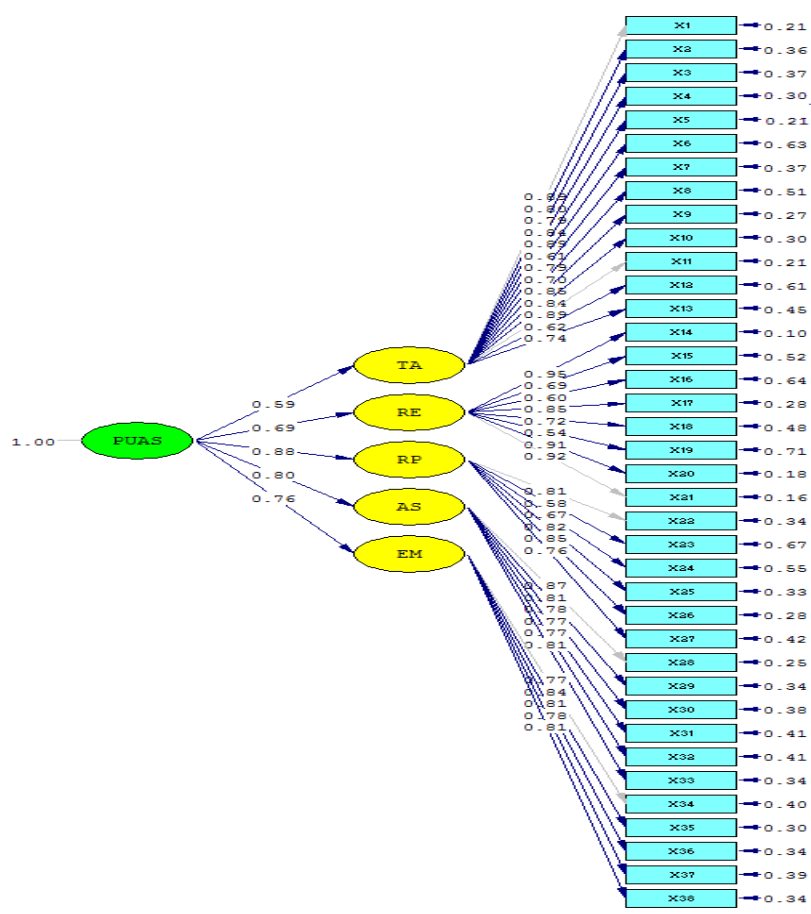

Gambar I. Nilai Loading Factor Masing-masing Butir untuk Tiap-tiap Dimensi pada Model Uji Coba I (Kinerja)

Hasil perhitungan ujicoba pengujian validitas instrumen harapan dengan 38 butir valid. Sedangkan uji reliabilitas dengan menggunakan formula koefisien reliabilitas Alpha Cronbach pada masing-masing dimensi pada instrumen harapan didapatkan nilai koefisien reliabilitas untuk masing-masing dimensi mempunyai nilai Alpha Cronbach lebih besar dari 0,7. Nilai koefisien reliabilitas tersebut dikatakan tinggi, sehingga instrumen kepuasan siswa ini digunakan sebagai alat ukur yang handal.

Untuk perhitungan AVE dan $C R$ dilakukan secara bertahap, pertama untuk first order konstruk dan kedua untuk second order konstruk. Berikut hasil perhitungan nilai AVE dan CR untuk setiap konstruk pada instrumen harapan ditunjukkan oleh Tabel 4.

Tabel 4. Nilai AVE dan Reliabilitas Konstruk pada Model Ujicoba I (Harapan)

\begin{tabular}{ccc}
\hline Konstruk & AVE & CR \\
\hline Kepuasan Siswa & $0,58 \mathrm{I}$ & $0,98 \mathrm{I}$ \\
\hline
\end{tabular}

Nilai loading factor masing-masing item pada tiap-tiap dimensi pada instrumen kinerja dapat dilihat pada Gambar 2 berikut ini.

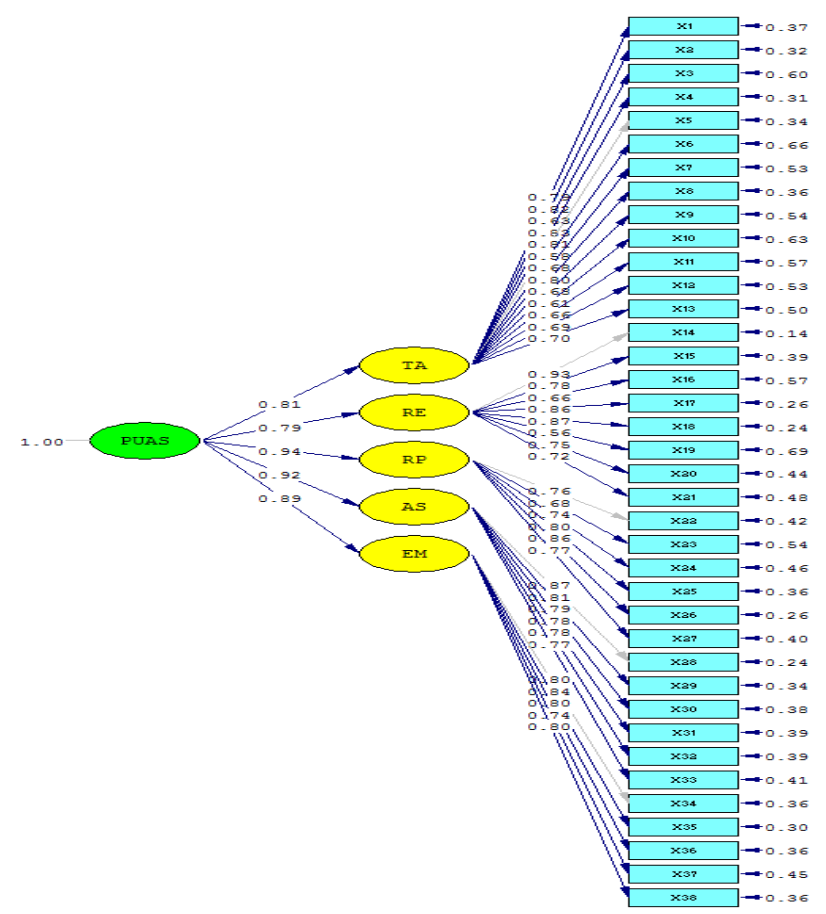

Gambar 2. Nilai Loading Factor Masing-masing Butir untuk Tiap-tiap Dimensi pada Model Ujicoba I (Harapan)

Dari Gambar 2 dapat diketahui bahwa seluruh indikator signifikan karena memiliki nilai loading factor $>0,5$. Hal ini dapat dikatakan bahwa item/indikator penyusun masing-masing dimensinya dapat menjelaskan konstruk latennya dengan baik. Hal ini memberikan makna bahwa seluruh indikator memberikan informasi yang signifikan terhadap variabel latennya.

Karena model fit secara keseluruhan, nilai loading factor masing-masing indikator pada setiap dimensi lebih dari 0,5 ; nilai $A V E>0,5$; dan nilai reliabilitas konstruk yang tinggi maka dapat dikatakan bahwa model ini sudah baik dan tidak memerlukan adanya perbaikan/modifikasi. Hasil yang serupa didapatkan pada ujicoba empiris kedua.

Dari hasil analisis secara kuantitatif dan kualitatif, secara umum dapat dikatakan bahwa instrumen pengukur tingkat kepuasan siswa terhadap kualitas pelayanan di sekolah yang dikembangkan berdasarkan kajian teoretik dan telaah para pakar dan panelis serta diujicoba secara empiris di beberapa SMA, sudah sesuai dan dapat diaplikasikan pada penilaian kualitas/mutu pelayanan di sekolah. Jika dibandingkan konsep dan draft awal dari perangkat non tes, terdapat 
beberapa perbaikan/revisi dan pengembangan sebagai hasil dari ujicoba rasional oleh pakar dan panelis serta ujicoba empiris kepada responden di lapangan baik tahap pertama maupun tahap kedua. Pengembangan tersebut mencakup kesesuaian antara butir dengan indikator, indikator dengan dimensi pada konstruk latennya, serta penggunaan bahasa yang lebih komunikatif dan dapat dipahami oleh responden.

Validitas berkaitan dengan sejauh mana suatu tes mampu mengukur apa yang seharusnya diukur. Instrumen yang dikembangkan ini memiliki validitas yang memadai, baik validitas konstruk hasil penilaian pakar dan panelis, validitas butir dan validitas konstruk hasil ujicoba empiris. Validitas konstruk dilihat pada kesesuaian antara butir dengan indikatornya, indikator dengan dimensi pembentuk konstruk latennya. Hasil penilaian para pakar menunjukkan bahwa instrumen non tes ini memiliki validitas konstruk yang memadai. Dengan demikian, instrumen pengukur tingkat kepuasan siswa ini dapat digunakan di jenjang SMA, baik negeri maupun swasta.

Reliabilitas suatu alat ukur merupakan konsistensi atau keajegan alat ukur tersebut dalam mengukur apa yang diukur. Makin tinggi koefisien reliabilitas, makin dekat nilai skor amatan ke nilai komponen skor yang sesungguhnya, sehingga nilai skor amatan dapat digunakan sebagai pengganti komponen skor yang sesungguhnya. Dengan demikian dapat dinyatakan bahwa instrumen ini dapat dikatakan valid dan reliabel.

Berdasarkan hasil penilaian instrumen harapan siswa dan instrumen kinerja maka akan didapatkan suatu perhitungan mengenai tingkat kesesuaian antara harapan dan kinerja yang dirasakan oleh siswa. Tingkat kesesuaian adalah hasil perbandingan skor kinerja dengan skor harapan. Tingkat kesesuaian inilah yang akan menentukan tingkat kepuasan siswa. Jika tingkat kesesuaian sama dengan 100\% atau lebih, maka siswa dinyatakan puas atau sangat puas. Jika tingkat kesesuaian kurang dari 100\%, maka siswa dinyatakan tidak puas pada atribut pernyataan tersebut. Selain itu, tingkat kesesuaian juga dapat menentukan urutan prioritas yang mempengaruhi tingkat kepuasan siswa.

\section{Simpulan}

Berdasarkan hasil ujicoba yang didapatkan dari hasil penelitian, dapat disimpulkan beberapa hal sebagai berikut: pertama tingkat kepuasan siswa terhadap kualitas pelayanan pendidikan tersusun atas lima dimensi, yaitu: (I) tangible, (2) reliability, (3) responsiveness, (4) assurance, dan (5) emphaty.

Kedua, pengujian validitas konstruk dilakukan pertama kali oleh pakar dan panelis untuk melihat sejauh mana penjabaran indikatorindikator dan butir telah membentuk susunan atau kerangka konsep konstruk yang diujikan, yaitu: kepuasan siswa terhadap kualitas pendidikan di sekolah. Setiap indikator dikaji, butir-butir pernyataan mana saja yang sesuai dengan indikator tersebut. Setiap indikator dijabarkan ke dalam butir-butir pernyataan secara memadai. Dari hasil pengujian ini ada dua butir yang dinyatakan gugur karena dinilai tidak sesuai dengan konsep yang akan diukur. Kemudian butir yang tersisa, yaitu: ada 38 butir yang mendasari indikator-indikator pada tiap-tiap dimensi.

Ketiga, perhitungan koefisien reliabilitas multidimensi pada ujicoba empiris pertama didapatkan nilai loading factor untuk masingmasing item lebih dari 0,5 , nilai average variance extracted (AVE) konstruk lebih dari 0,5 dapat dinyatakan bahwa instrumen memiliki validitas yang memadai dan nilai koefisien reliabilitas multidimensi yang tinggi dapat dikatakan bahwa instrumen pengukur tingkat kepuasan siswa terhadap kualitas pelayanan pendidikan di sekolah sangat handal (reliabel).

\section{Daftar Pustaka}

Fornell, C., dan David F. Larcker. (198I). Evaluating Structural Equation Models with Unobservable Variable and Measurement Error. Journal of Marketing Research, Vol. I8: 39-50.

Giese, Joan L., dan Joseph A. Cote. (2002). Defining Consumer Satisfaction." Academy of Marketing Science Review, Vol. 2000: I-24.

Hair, J. F., R.E. Anderson, Barry J. Babin, dan William C. Black. (20I0). Multivariate Data 
Analysis. New Jersey: Pearson Prentice Hall, Inc.

Kotler, Philip, dan Gary Armstrong. (20/2). Principles of Marketing. New Jersey: Prentice-Hall, Inc.

Kotler, Philip, dan K. L. Keller. (20I2). Marketing Management. New Jersey: Prentice Hall.

Latan, Hengky. (20I3). Model Persamaan Struktural Teori dan Implementasi AMOS 2 1.0. Bandung: Alfabeta, 2013.

Margono, Gaguk. (2005). Validasi Konstruk Instrumen Pengukur Kepuasan Mahasiswa Sebagai Pelanggan Internal. Jurnal PTM, Vol. $5(I): I-10$.

Naga, Dali S. (20I2). Teori Sekor pada Pengukuran Mental. Jakarta: PT. Nagarani Citrayasa.

Oliver, Richard L. (1980). A Cognitive Model of the Antecedents and Consequences of Satisfaction Decisions. Journal of Marketing Research, Vol. 17: 460-469.

Parasuraman, A., V. A. Zeithaml, dan L. L. Berry. (1985). A Conceptual Model of Service Quality and its Implications for Future Research. Journal of Marketing, Vol. 49: 4I50 .

Parasuraman, A., V. A. Zeithaml, dan L. L. Berry. (1994). Reassessment of Expectations as A Comparison Standard in Measuring Service Quality: Implications for Future Research. Journal of Marketing, Vol. 58: I I I-I24.

Parasuraman, A., V. A. Zeithaml, dan L. L. Berry. (1998). SERVQUAL: A Multiple-item Scale for Measuring Consumer Perceptions of Service Quality. Journal of Retailing, Vol. 64(I): 12-40.

Parasuraman, A., V. A. Zeithaml, dan L. L. Berry. (1993). The Nature and Determinants of Custumer expectation of Service. Journal of
The Academy of Marketing Science, Vol. 2I(I): I-I2.

Supranto, J. (201 I). Pengukuran Tingkat Kepuasan Pelanggan untuk Menaikkan Pangsa Pasar. Jakarta: Rhineka Cipta.

Sureshchandar, G.S., Chandrasekharan Rajendran, dan R.N. Anantharaman. (2002). The Relationship between Service Quality and Customer Satisfaction-A Factor Specific Approach. Journal of Services Marketing, Vol. 16: 363-379. 